\title{
Kelet-Közép-Európa térszerkezeti képe
}

\section{The spatial structure of East-Central Europe}

\author{
SZABÓ PÁL, FARKAS MÁTÉ
}

SZABó Pál: egyetemi adjunktus, Eötvös Loránd Tudományegyetem, Regionális Tudományi Tanszék, Budapest; szabopalpeter@t-online.hu

FARKAS Máté: PhD-hallgató, Eötvös Loránd Tudományegyetem, Regionális Tudományi Tanszék, Budapest; fampadt427@gmail.com

KULCSSZAVAK: Kelet-Közép-Európa, térszerkezet, csomópont, tengely, zóna

ABSZTRAKT: Tanulmányukban Kelet-Közép-Európa térszerkezeti képének felvázolására teszünk kísérletet. A tanulmány első részében elsőként három alapvető térszerkezetfelfogást írunk le, amelyekből a mennyiségi és minőségi jegyeket egyszerre ábrázoló módszert választunk elemzésünkhöz. Ezt követően a térszerkezet lehetséges alkotóelemeit (csomópont, tengely, zóna) tárgyaljuk, elméleti és gyakorlati oldalról, megalapozva a térségi vizsgálat szempontjait. A következő lépésben az európai térszerkezeti kettősséget (Banán vagy Szőlő) elemezzük, rámutatva a mennyiségi és a minőségi dimenzió ütközésére, valamint Kelet-Közép-Európa térszerkezeti pozícióját tárjuk fel: holdudvari szerepkör másodlagos, harmadlagos súlyú térszerkezeti elemekkel. A tanulmány második felében Kelet-Közép-Európa térszerkezeti ábráját alkotjuk meg, olyan módon, hogy egyrészt a gazdasági fejlettség és sűrüség regionális térképei alapján zónákat határozunk meg, másrészt a nagyvárosok kiemelése, kategorizálása alapján különböző típusú csomópontokat alkotunk, harmadrészt a közlekedési folyosókat tengelyekként rögzítjük, és végezetül mindezeket ábrára visszük.

Pál SZABÓ: assistant professor, Department of Regional Science, Eötvös Loránd University, Budapest; szabopalpeter@t-online.hu

Máté FARKAS: PhD student, Department of Regional Science, Eötvös Loránd University, Budapest;fampadt427@gmail.com

KEYWORDS: East-Central Europe, spatial structure, node, axis, zone

ABSTRACT: The aim of this paper is to explore and analyze the main characteristics of EastCentral Europe's spatial structure and its changes during the recent years. In the first section we summarize the theoretical foundations of the notion and the elements of spatial structure, mainly based on our previous research. We discuss the complex way of the description of spatial structure (the regional development inequalities and the differences of socio-economic concentration), and analyze its three main elements (node, axis, zone). The next part reviews some recent and older literature about the changing ideas and approaches of spatial structure of Europe. We also describe the macroregion's position in the spatial structure of Europe. The main difference between the point of views is whether the continent shows a polycentric spatial structure or a centre-periphery model, and whether East-Central Europe is a semi-periphery of

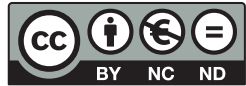


the continent or a potential economic centre. Finally, based on the literature synthesis and our own calculations based on regional data provided by Eurostat, we trace the spatial structure of the macroregion. The more and less developed zones show a West-East contrast with some segregated, more developed regions in the Eastern part, but there isn't a large socio-economic central area. The nodes are not concentrated, they have different social and economic weights, and the axes are probably the Pan-European corridors. The main change of the spatial structure in the 2000s is that the Southern part of the macroregion has become more homogeneous (a less developed zone).

\section{Bevezetés}

Tanulmányunk célja Kelet-Közép-Európa klasszikus térszerkezeti képének megalkotása. A munka első részében az elméleti alapokat foglaljuk össze röviden, külön kiemelve a térszerkezeti alkotóelemeket és jellemzőiket. A második részben ezek tükrében egyrészt áttekintjük a Kelet-Közép-Európa térszerkezetéről alkotott elképzeléseket, másrészt saját számítások, elemzések révén vázoljuk fel a térség - értelmezésünk szerinti - térszerkezetét, külön tekintettel arra, hogy az miként változott az elhíresült kelet-európai bumeráng ábrájának keletkezése óta.

Munkánk alapvetően elemzői, nem fejlesztői szemléletü, ugyanakkor egyes részeknél kitérünk a téma területfejlesztési vonatkozásaira is. A számításokhoz az Eurostat regionális adatbázisát használtuk fel, mivel témánk és vizsgált térségünk szempontjából jelenleg ez az egyetlen megbízható, összehangolt regionális és nagyvárosi adatbázis. ${ }^{1}$

\section{A térszerkezet értelmezése és alkotóelemei}

Ahhoz, hogy térszerkezeti ábrát készíthessünk, szükséges tisztázni a fogalom jelentését és alkotóelemeit. A területi jellemzőkkel foglalkozó társadalomtudományi és szakpolitikai körben a térszerkezet fogalma nem egyértelmű. A hazai tudományos értelmezések alapján háromféle nézőpont azonosítható: a térszerkezet az alkotóelemek és azok elrendeződése; a térszerkezet az alkotóelemek összessége; a térszerkezet az alkotóelemek egymáshoz viszonyított helyzete (részletesebben lásd Szabó 2008). A különböző térszerkezet-felfogások egy másik szempont, a leírás, elemzés (és beavatkozás) szerint is osztályozhatók, ez alapján a hazai gyakorlatban háromféle szemlélet van jelen (részletesebben lásd Szabó 2008):

- az egyik a földrajzi környezet elemeihez, ezen belül a különböző földrajzi térségtípusokhoz (pl. földhasználati besorolás), a település- és infrastrukturális hálózatokhoz stb. mint térszerkezeti egységekhez kötődik; ez inkább földrajzi, területrendezési szemlélet, a földrajzi térben érzékelhető „dolgokról”, ezek abszolút volumeneiről (társadalmi, gazdasági súly) szól; 
- a másik a területi egyenlőtlenségek kutatása során a területegységek közötti mennyiségi és minőségi differenciák feltárása révén fogalmazza meg a térszerkezetet; ez inkább regionalista, területfejlesztési szemlélet;

- a harmadik lehetőség a két szemlélet ötvöződése; munkánkban mi is ezt a közelítésmódot alkalmazzuk.

Bár a szakmabeliek szerint sok mindennek van térszerkezete (etnikumok, ipar stb.), ám ha általánosan esik szó egy térség térszerkezetéről, akkor a hazai és nemzetközi szakirodalom összetett, soktényezős társadalmi-gazdasági térszerkezetről beszél, amely erősen kötődik a társadalmi-gazdasági koncentrációk és ritkulások, a centrumok és perifériák, valamint a fejlettség és elmaradottság jelenségeihez.

Ebből a gondolati körből kiindulva Rechnitzer $(2013,38$.) kiemeli, hogy „a térszerkezeti elemzések célja tehát annak megállapítása, hogy a vizsgált nagyobb területi egység - lehet ország vagy országok csoportja, együttese - milyen közös jellemzőkkel rendelkező egységekből, összetartozó ismérveket mutató, térben is - valamilyen szempont szerint - lehatárolható alkotóelemekből áll, s ezek az elemek a jövőben milyen irányban fejlődhetnek, változhatnak." Ennek kapcsán célszerű az időbeli dimenziót vizsgálni: fel lehet tárni múltbeli térszerkezetet, azonosítani lehet az aktuális, jelenbeli térszerkezetet, és fel lehet rajzolni valamiféle jövőképet (jövőképeket) - utóbbinál a várható, spontán kialakuló területi képet vagy az elérendő célt ábrázolva. Itt lép a képbe a területpolitika (Rechnitzer, Smahó 2011), mivel e szakpolitikában egyrészt rögzíthetnek egy aktuális térszerkezeti képet, másrészt megalkothatják a beavatkozások hatására remélt térszerkezeti képet.

Földrajzi térről lévén szó, természetesen megkerülhetetlen a térképi ábrázolás. Az egyik kérdés, hogy milyen ábratípusra használjuk a térszerkezet nevet. Felfogásunkban a térszerkezet kifejezést a földrajzi tér társadalmi-gazdasági jellemzőit szelektíven, generalizáltan, egyszerüsítve szemléltető területi rajzolat esetében célszerü használni, ez leginkább általános és tematikus térképek „továbbvezetésekor”, kombinálásakor jelenik meg. Ráadásul, véleményünk szerint, szűkíthető a kör a társadalmi-gazdasági koncentrációkhoz és a fejlettséghez köthető ábrákra. A másik dilemma maga az elnevezés: ábra vagy modell? Felfogásunkban inkább térszerkezeti ábráról (képről) van szó, ha egy konkrét földrajzi teret akarunk ilyen módon bemutatni, és a modell kifejezést a térbeli törvényszerűségek általános térbeli ábrázolásának hagynánk meg. Ugyanakkor ezt a gyakorlat inkább modellként említi, építve a földrajzi tér modellezésének folyamatára, a valós világ absztrahálására (ikonikus, analóg, szimbolikus modellek) (Haggett 2006; részletesebben lásd Szabó 2012a).

A következő lényeges kérdés, hogy miket tekintünk egy térszerkezeti ábra alkotóelemeinek. A hazai és külhoni sokszínűség ezen a téren érzékeltethető (Szabó 2010, 2011, 2012b), ám az ismétlődo „motívumok” alapján véleményünk szerint háromféle csoport alkotható: csomópontok, tengelyek és zónák (határokkal).

A csomópontok (centrumok, központok, pólusok stb.) létüket annak köszönhetik, hogy a társadalom és a gazdaság területi sűrüsödése (illetve ritkulása, akár 
hiánya) alakul ki: az általános értelemben vett csomópontok esetében a népesség, a gazdasági tevékenység, a beépítettség stb. térbeli koncentrációja figyelhető, mérhető meg; jelzős szerkezetű csomópontok esetében pedig ezek egy vagy több szegmense. A csomópont napjainkban kifejezetten a nagyvárosokat, nagyvárosi agglomerációkat jelenti, városok összefüggő formációi viszont már a zóna kategóriába sorolhatók. A csomópontok közötti különbséget a koncentrációk nagysága, valamint a betöltött funkciók, és azok száma jelenti; a kettő azonban nem mindig nő együtt. A nagyvárosokat e szempontok alapján szokták kategorizálni, a térszerkezeti csomópontokat ábrázolni. A koncentrációnak más formái is lehetnek, megemlíthetők a nagy súlyú, pontszerü, nagyvároson kívüli turisztikai desztinációk (pl. zarándokhelyek), bányászati-ipari centrumok, logisztikai, közlekedési, vagy akár K+F-csomópontok (pl. technopoliszok). Dilemmát okoz a csomópontok esetében pontszerüségük (kiterjedésük) és hatósugaruk (vonzáskörzetük) értelmezése, ábrázolása.

A második térszerkezeti elem a tengely (folyosó, sáv stb.). Az előzőhöz képest ez a formáció kevésbé egyértelmű, mivel különbséget lehet tenni aközött, amikor kifejezetten áramlási, összekötő tengelyről, valamint amikor társadalmi-gazdasági tengelyekről (csápokról stb.) beszélünk. Az első esetben a lényeg a tengely végein van (kiindulás és érkezés, általában két csomópont között), a tengely funkciója az átvitel. Fő típusa a közlekedési tengely, amelynél a különböző formák (légi, folyami, közúti, vasúti, csővezetékes szállítás) között eltérés van a tekintetben, hogy csak két végpont közötti áramlásról van szó (és alagúthatás lép fel) vagy koncentráció alakulhat ki a tengely mentén lévő pontokban (például autópálya-lehajtók, köztes vasútállomások). A modern korban a csomópontok közötti áramlásban nagy és növekvő szerepe van a földrajzi téren, az itt vizsgált klasszikus térszerkezeten „túllépő” formáknak (információ, tőke stb. áramlása). A második esetben olyan területekről beszélünk, ahol a koncentráció a földrajzi térben megnyúlt alakot ölt, központ nélkül. Kialakulására jellemző, hogy az áramlási tengelyek egyes részeinél indul meg és innen terjed el térben a társadalmi-gazdasági sűrűsödés. Mindkét alcsoport esetében a térképi ábrázoláshoz kiemelés és kategorizálás szükséges, nagyság (áramlási forgalom, sürűsödés), illetve rang (például kiemelt közlekedési folyosók, hivatalosan lehatárolt agglomeráció) alapján.

A harmadik típus, a zóna jellemzője, hogy nagyobb kiterjedésű az előzőekhez képest. A csoport minőségi és mennyiségi szempont szerint lehatárolt zónákra bontható. Az első esetben a fejlett és elmaradott, a második esetben a magas és alacsony társadalmi vagy gazdasági súlyú, nagyobb kiterjedésű területek beazonosítása és ábrázolása történik. A zónák speciális esete, amikor tartalmuk nem komplex, hanem egy-egy ágazathoz kötődik: térszerkezeti szempontból a nagyobb kiterjedésű, sűrü agrárzónák, bányászati-ipari körzetek, turisztikai térségek (tengerpart stb.) emelhetők ki; ezek speciális térszerkezeti elemekként megjelenhetnek az ábrákon.

A térszerkezeti elemzés szempontjából lényeges az egyes elemek területi elhelyezkedése (sürüsödésük, ritkulásuk, csoportosulásuk stb.), valamint más tér- 
szerkezeti elemekhez való kapcsolódásuk (érintkezés, benne foglaltatás stb.). Például a koncentrációk és zónák kombinálódhatnak (egy terület egy zóna része, de koncentráció is). A térszerkezeti összetettség keveredést is okozhat, főként ha nem egyértelmű, hogy mennyiségi vagy minőségi jegyek, esetleg mindkettő alapján osztályozzuk a földrajzi teret (pl. szegény vagy gazdag nagyvárosok (koncentrációk), szegény vagy gazdag vidék). Ugyanakkor egy térszerkezeti ábrán - a célból eredő „területi hangsúlyozás” miatt - gyakorta maradnak köztes terek (névtelen, fehér foltok), emiatt is különbözik egy területi elemzés tematikus térképétől, ahol az egész földrajzi teret kategorizáljuk. A különbség oka a térszerkezeti ábra célja: nem a részletes, teljes körü bemutatás, hanem a lényeg kiemelésével átfogó területi kép nyújtása.

Végezetül fontos megemlíteni, hogy a területi kutatásokon túl a területpolitika, azon belül a területi tervezés is használ térszerkezeti ábrákat: dokumentumaikban manapság gyakorta felbukkannak ábrák, ahol a csomópontok, tengelyek beazonosítása, elmaradott zónák lehatárolása, és mindezek fejlesztési célú kijelölése figyelhető meg. (Ezekre e cikkben nem térünk ki részletesen.)

Az itt leírt elemtípusokat számos térszerkezeti ábra tartalmának szintéziseként fogalmaztuk meg. Az elemek terén különösen a kelet-közép-európai országok tudományos és szakpolitikai gyakorlata mutat nagyfokú hasonlóságot (Szabó 2012b). Viszont tény az is, hogy egy-egy országban a térszerkezet kifejezés nem jelenik meg (pl. Spanyolországban - Farkas 2010), valamint egyes országokban (pl. a Független Államok Közösségében) még nem igazán hódít a térszerkezet-központú irányzat. Feltételezhető, hogy a szemlélet és a hozzá párosuló ábrázolási technika egy szakmai körből kiindult, majd egyre több helyen teret nyert. Készültek ilyen ábrák az európai kontinensre és makrorégióira, benne Kelet-Közép-Európára, valamint különböző országokra, régiókra. (Roger Brunet francia geográfus és az általa vezetett Reclus-kutatócsoport anyagai gazdagok ilyen ábrázolásokban, már az 1980-as évektől.) A hazai területkutatói, területfejlesztői kör a térszerkezet fogalmát évtizedek óta használja, a klasszikus térszerkezeti ábrák viszont igazából a kilencvenes-kétezres években terjedtek el, és számos, kifejezetten térszerkezeti elemzés és a tematikus térképeken túllépő ábra készült az országra, térségeire, tágabb környezetünkre.

\section{Európai térszerkezet-szemléletek és Kelet-Közép-Európa térszerkezeti szerepe}

Az elmúlt évtizedekben az európai kontinensre számos térszerkezeti ábra készült, és a nagy elemszámból eredően már csoportosítani is lehet ezeket forma, tartalom és szemlélet szerint (Szabó 2009). Ebből témánk szempontjából az a lényeges, hogy mi az uralkodó térszerkezet-szemlélet, valamint miként jelenik meg Kelet-Közép-Európa ${ }^{2}$ kontinensünk térszerkezetében. 
Egy időben meghatározó volt, de még ma is gyakorta kiemelt területi kutatási cél a kontinens legfejlettebb zónájának lehatárolása, a centrum-periféria szemlélet érvényesülése (ennek legismertebb példái a Kék banán és az EU szakpolitikai köreiben egy időben teret hódított Pentagon voltak). Több vizsgálat tett kísérletet az újabb centrumtérségek, fejlődő zónák lehatárolására (ezek eredményei lettek például az Európai napfényövezet, Kereszt banán, Kelet-közép-európai bumeráng stb.), azonban e formációk léte többek szerint vitatható (pl. Kincses, Nagy, Tóth 2013), így egyes szakmai körökben a Kék banán (az egyetlen centrum) elképzelése ma is domináns (pl. BBSR 2011; Kincses, Nagy, Tóth 2013). A kilencvenes években ugyanakkor az európai térszerkezetben egy másik elemtípus, a csomópontok (nagyvárosok) váltak egyre hangsúlyosabbá, és egyre nagyobb teret nyertek a térszerkezetről való gondolkodásban (policentrikus szemlélet), sőt ez idővel szembe is fordult az összefüggő zónát hangsúlyozó Kék banánnal; ennek Kunzmann (1992) Európai szőlő modellje az emblematikus példája. (Az elmúlt időszakból a policentrikus kontinenst igazolja pl. Dijkstra, Annoni, Kozovska 2011.) A szembenállásban a korábban emlegetett térszerkezeti kettősség is benne van. Napjainkban a nagyvárosok, nagyvárosi térségek növekvő szuperkoncentrációk, amelyek csomópontokként, illetve ezek sűrűsödéseként vannak jelen a térszerkezetben (Szőlő). Ráadásul kimutatható (Fábián 2011), hogy az európai generális szomszédsági hasonlóság (és hatás) kezdi érvényét veszteni; emiatt kérdéses, hogy lehet-e még nagy, összefüggő zónákat lehatárolni. Véleményünk szerint egy köztes állapot van: a népsürüség és a gazdasági sürüség, valamint az egy före jutó GDP regionális adatai alapján jelenleg is megfogható egyfajta központi (de szakadozott) zóna Európában, amely döntően fejlett és döntően koncentrál - ez pedig a Kék banán alakzatát adja vissza. Rajta kívül, de már nem összefüggően, társadalmi, gazdasági csomópontok is fellelhetők az európai térben (nagyobbrészt fejlett nagyvárosi régiók), valamint találunk még fejlett vidéki tereket koncentráció nélkül vagy koncentrációt szórványokkal (főként az Alpokban és Észak-Európában). Kérdés, hogy mindezek a jegyek miként érvényesülnek a vizsgált térségben.

Kelet-Közép-Európa megjelenéséről az állapítható meg, hogy a hetvenesnyolcvanas években az összeurópai térszerkezeti kép megalkotása nem volt jellemző Nyugat-Európában, a kontinens „nyugati” fele volt csak a vizsgálati alany. A rendszerváltozás után viszont bővült a kutatási tér, megjelentek az egész kontinenst átfogó térszerkezeti vizsgálatok és ábrák. Ezekből itt annyit emelünk ki, hogy Kelet-Közép-Európa egy köztes tér az európai magterület és a keleti periféria között, nem része a centrumterületnek, hanem inkább holdudvara, s bár több elképzelés potenciális centrumterületként tekint rá, ez még elég távolinak tűnik. Ha a csomópontokat és a tengelyeket nézzük KeletKözép-Európában, megállapítható, hogy súlyukat, funkcióikat tekintve a legkiemelkedőbbek is csak másod- vagy harmadrendűek az összeurópai földrajzi térben, mindössze Bécs jelenik meg érdemi csomópontként. (Bár újabb vizs- 
gálatokban - pl. BBSR 2011; GAWC 2012 -, ahol nem a volumen, hanem a funkciók gazdagsága felől közelítenek a csomópontokhoz, több térségbeli föváros is előkelő pozíciót ért el.)

\section{Kelet-Közép-Európa térszerkezete vizsgálataink alapján}

Kelet-Közép-Európára rajzolt, értelmezésünk szerinti térszerkezeti ábrára nem bukkanunk a szocialista időszak munkáiban. „Az európai szocialista országok területi fejlődésének együttes gazdaságföldrajzi vizsgálata (...) elsősorban leíró, nem kvantitatív jellegü munkákban kapott helyet. Az országcsoport-szintü összevetés jórészt egy-egy ágazatra" korlátozódott (Nemes Nagy 1987, 12.). Az első elhíresült ábra Gorzelak lengyel kutató alkotása a kilencvenes évek közepéről, amelyen az ún. Közép-európai bumeráng a kulcselem (1. ábra). Gorzelak (1996) megállapította, hogy Kelet-Közép-Európában a rendszerváltozást követően fejlődésnek indultak az infrastruktúrával legjobban ellátott, innovációk befogadására legalkalmasabb fóvárosi térségek, valamint az országok nyugati övezetei és azok nagyvárosai (a kapuvárosok). Felfogása szerint e fejlődő térségek által megrajzolható övezet északon Gdańsktól indul és Poznań, Wrocław, Prága, Brno, Pozsony, Bécs érintésével Budapestig húzódik. A szerző - alakja miatt - a Közép-európai bumeráng elnevezést adta a zónának. A bumeráng azonban nem egységes, mivel kitüntetett szerepet kapnak benne a központok és magterületek (leginkább Prága, Budapest, Bécs-Pozsony, illetve a zónán kívül Varsó) (Gorzelak 1996). E zóna azonban nem ér a Kék banán nyomába, hiszen utóbbi történeti gyökerekkel bír, városai gazdasági és társadalmi kapcsolatok ezernyi szálával kötődnek egymáshoz (Cséfalvay 1999).

Német kutatók egy másik formát készítettek erre a térségre. A Berlint, Prágát, Pozsonyt, Bécset, Budapestet magába foglaló fejlődési zóna (idézi Kunzmann 2001, aki elnevezte Uborkának) kissé módosított formája a Bumerángnak, mivel Németországból indul. A Bumeráng Gorzelak (1996) szerint gyorsan változó képződmény, így Berlin fejlődésével a kettős elágazás értelmet nyerhet.

Születtek még a térségre olyan térszerkezeti elképzelések, amelyek nem váltak szélesebb körben ismertté. Egyrészt Egri, Litauszky (2012) hívja fel a figyelmet Leibenath et al. munkájára: a szerzők a nyugat-európai Pentagon mintájára határoltak le egy Közép-európai pentagont (Berlin, Prága, Bécs, Budapest, Varsó csúcsokkal); ez a formáció megalkotói szerint a makrorégió centruma, ahol a népesség és GDP jelentős része összpontosul (Egri, Litauszky 2012 szerint 16\%-nyi területen a népesség 31\%-a és a GDP 41\%-a). Egy másik kutatásban „Új banánt” rajzoltak a térségbe (ez a potenciális második európai gazdasági magterület), amely az Uborkára hasonlít, de annál szélesebb kiterjedésủ és Ljubljanáig, Zágrábig húzódik (SIC! 2006). Utóbbi elfogadottsága nem ismert, ám mégis megjelent egy kiemelt hazai szakpolitikai dokumentumban, némileg módosított határokkal Kelet-európai banán néven módosítva. 
A hazai szakmai körökben nem készült bumerángszerü alakzat, mivel vagy a klasszikus területi különbségek feltárása, régiótípusok megalkotása volt a cél, és legfeljebb ívekkel történő zónalehatárolások jelentették a generalizálást, vagy maga a Bumeráng volt az elfogadott (pl. Cséfalvay 1999; Probáld, Szabó 2007; Rechnitzer 1998).

Kutatási célkitűzésünk az volt, hogy Rechnitzer (1998) térségi jellemzőket szintetizáló ábráját (1. ábra) aktualizáljuk. A térségre statikus formációt kívántunk megalkotni, az általános együttmúködési formák vizualizációja nélkül. Módszerünk az volt, hogy a három, korábban leírt építőelemet először egyesével megalkottuk, majd ezeket összegeztük egy ábrában.

1. ábra: Kelet-Közép-Európa térszerkezeti modellje az 1990-es években The model of East-Central Europe's spatial structure in the 1990s

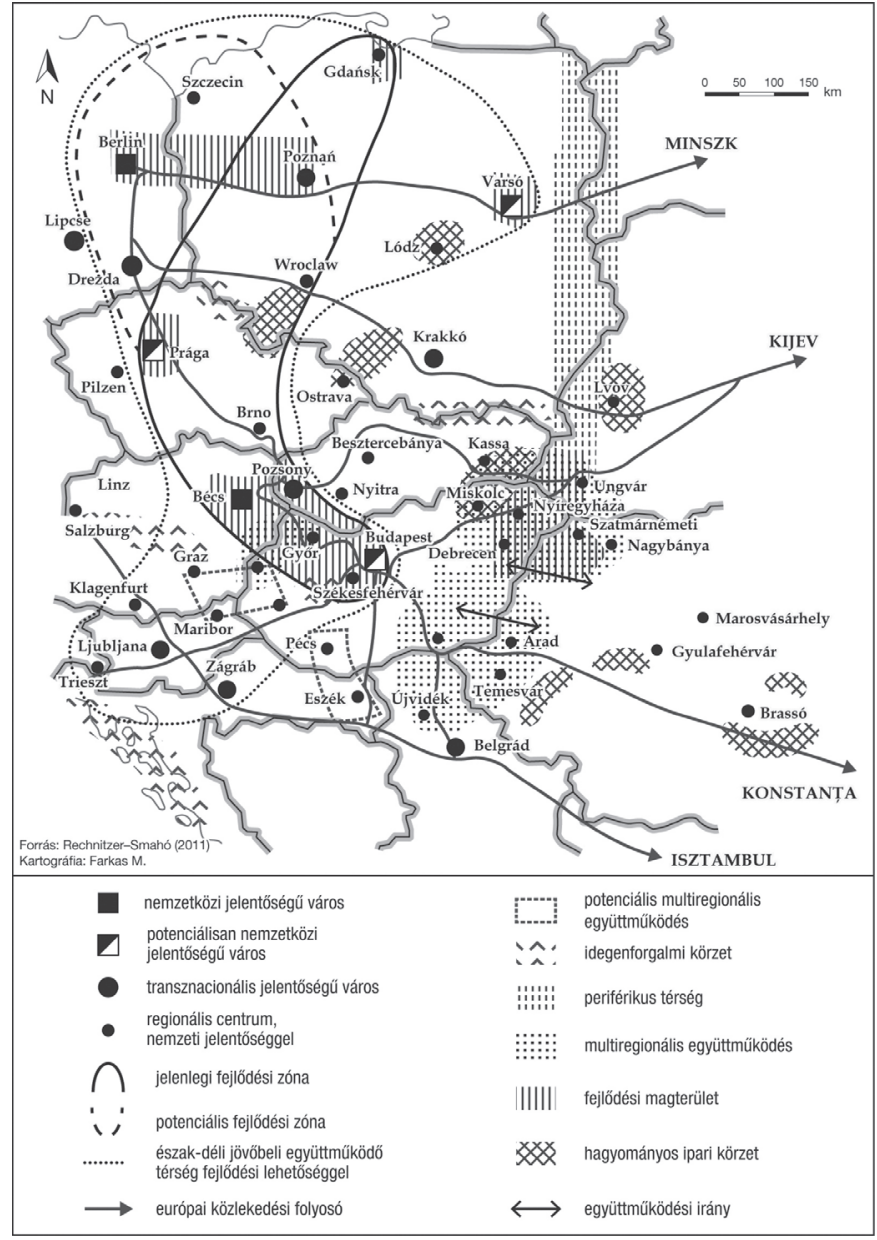

Forrás: Rechnitzer, Smahó 2011. 
Elsőként a zónákat azonosítottuk. Ez az eredeti ábrán egyrészt a Bumerángot és az Uborkát ötvöző centrumtérség-fomáció, benne néhány fejlődési magterülettel, másrészt a keleti végek perifériája. A térkategorizálást a regionális fejlettségi és gazdasági különbségek feltárásával kezdtük meg. Ilyen jellegű vizsgálatokból sok készült az elmúlt időszakban (hazánkban pl. Egri, Törőcsik, Tánczos 2009; Horváth 2009; Kuttor 2009; Lengyel 2012; Tagai 2004; külföldön pl. Artelaris, Kallioras, Petrakos 2010; Heyns 2005). Közös az ilyen munkákban, hogy jórészt a regionális egyenlőtlenségek és azok változásának vizsgálata, valamint egyes régiók csoportosítása volt a cél, ám a magterület és az elmaradott zónák konkrét térszerkezeti meghatározása és ábrázolása csak néhány esetben fordul elő - ezeknél az eredmények a fóvárosok kiemelt szerepét, valamint a nyugat-kelet ellentétet mutatják. A vizsgálatokban a területi keret is el-eltér, a módszereknek pedig gazdag tárházával találkozunk, ugyanakkor azok leginkább a GDP- és a GDP/fö-adatra vagy komplex mutatóra támaszkodtak, valamint a vizsgálatok döntően NUTS 2-es térségi szintüek. A precízebb ábrázolás miatt mi a NUTS 3-as szintet választottuk (218 alapegységgel), az elemzést pedig a gazdasági fejlettség (egy före jutó GDP) mellett a gazdasági sürüség (egy km²-re jutó GDP) ${ }^{3}$ 2010-es adataival készítettük el.

Az egy före jutó GDP (PPS) ${ }^{4}$ regionális különbségeinek térképén (2. ábra) kirajzolódik egy fejlett zóna Ausztriában, ezen kívül csak egyes fóvárosok emel-

2. ábra: A gazdasági fejlettség regionális különbségei Kelet-Közép-Európában, 2010 Regional inequalities of economic development in East-Central Europe, 2010
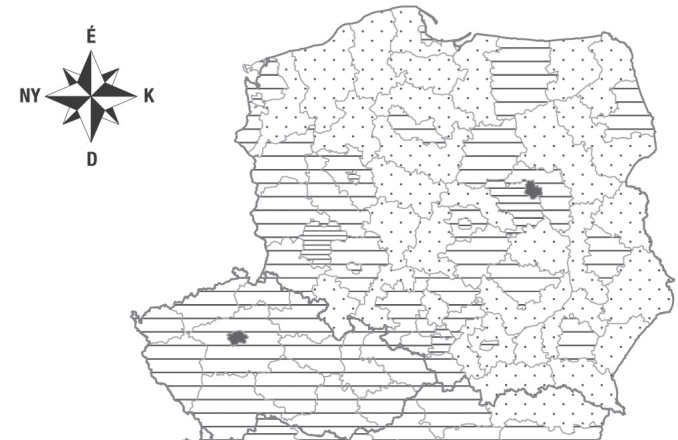

Az egy före jutó GDP értéke Kelet-Közép-Európa NUTS 3-as régióiban, 2010 (PPS) $(E U 27=100 \%)$
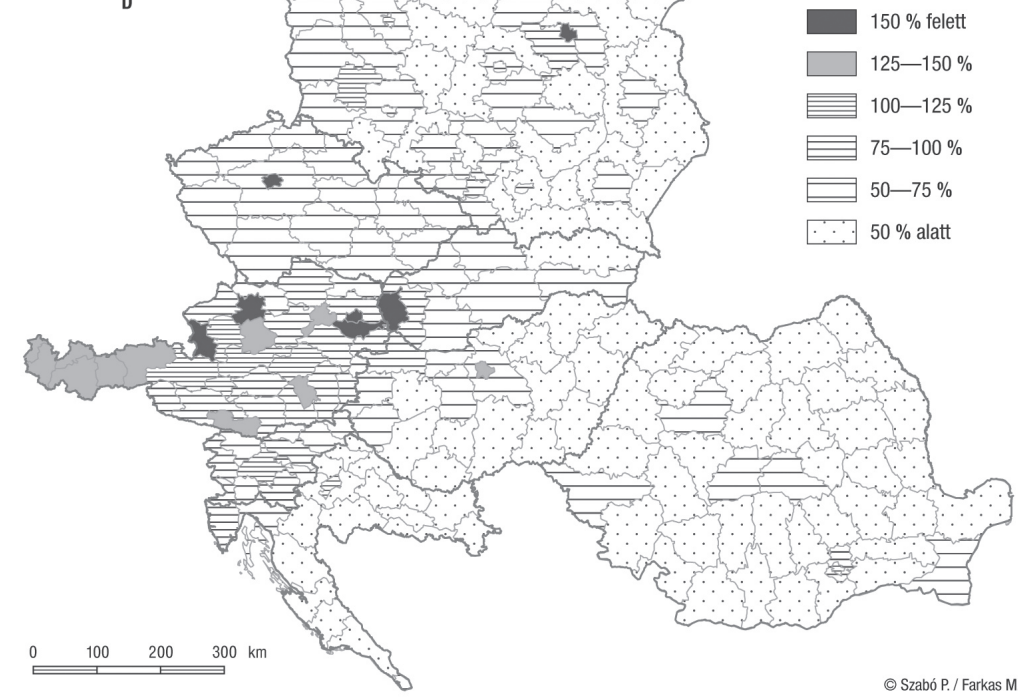

$50 \%$ alatt

C Szabó P. / Farkas M. 2014

Adatok forrása: Eurostat REGIO. 
kednek ki. A nyugati fejlett részt egy tágabb, nagyobbrészt összefüggő, közepesen fejlett zóna veszi körül Nyugat-Lengyelország, Csehország, Nyugat-Szlovákia, Közép- és Nyugat-Magyarország, Szlovénia és Nyugat-Horvátország területére kiterjedve; hasonló szintet továbbá egy-egy regionális nagyváros és annak térsége mutat. A többi földrajzi tér Kelet-Közép-Európa elmaradott részét jelenti. (Ez utóbbit finomítja Pénzes 2013 a legelmaradottabb kistérségek (LAU1) beazonosításával és ábrázolásával a makrorégióban.)

A gazdaság magterületeit jelző gazdasági sűrűség térképe (3. ábra) az előzőnél valamivel szakadozottabb és kevésbé nyugatcentrikus. Szembeötlő, hogy míg Ausztria csaknem összes régiója magas GDP/fó-értékkel bír, addig a területre vetített GDP-értékek alapján csupán néhány térsége emelkedik ki. A „szőlőmodell" igazi, Európa egészénél is nagyobb érvényességét mutatja, hogy a gazdasági sűrűség rangsorának első felében szinte kivétel nélkül urbánus régiók, fövárosi térségek állnak, és ezek a centrumtérségek nem alkotnak összefüggő zónát. A csomópontok közül kiemelkedik Bécs és szűkebb vonzáskörzete,

3. ábra: A gazdasági sűrűség területi különbségei Kelet-Közép-Európában, 2010 Regional inequalities of economic density in East-Central Europe, 2010

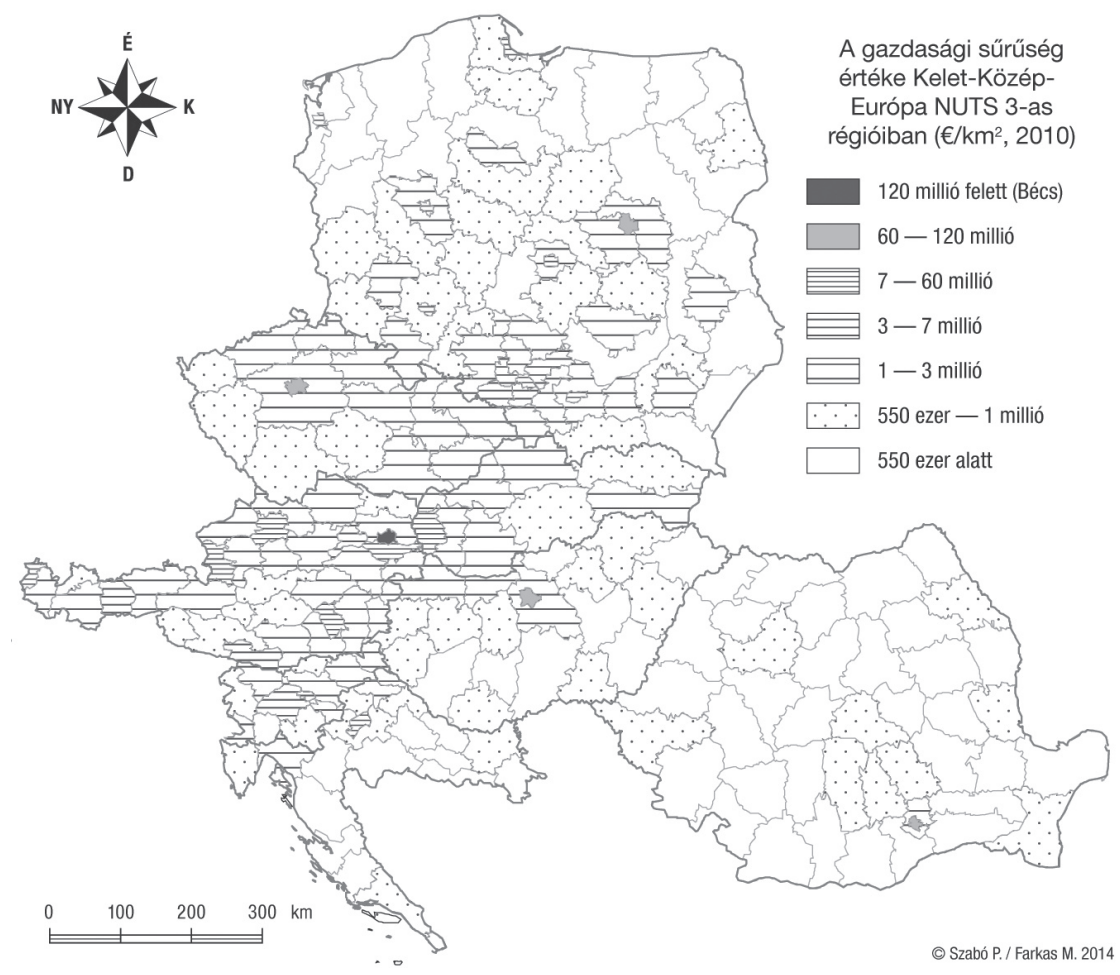


valamint Bukarest, Budapest, Prága és Varsó régiója, amelyeket Zágráb és Pozsony, a lengyelországi tengerparti „városhármas” (Gdańsk-Gdynia-Sopot), valamint több lengyel és osztrák nagyváros követ. A perifériának számító területek összefüggően főleg Lengyelország északi és keleti térségében, hazánkban a Dél-Dunántúlon és a Dunától keletre, Horvátország keleti részén, valamint a fóváros és térségén kívül egész Romániában megfigyelhetők.

Ha összekapcsolódó sürü zónát keresünk, akkor az 1-3 millió eurós értékkategóriába tartozó, közepes gazdasági sürüségü térségek alkotnak az előbb leírt csomópontokkal egy alakzatot, amely azonban nem kötődik szorosan a nyugati részhez (egyes lengyel, cseh, osztrák, szlovén nyugati, vidékies régiók relatíve alacsonyabb gazdasági sürüségűek), és véleményünk szerint a tagoltság miatt egy összefüggő alakzatot feltehetőleg nem is célszerü felrajzolni (egy kissé szakadozott, ágas-bogas alakzat tünne fel az ábrán). Összességében nem lehet érzékelni nagy kiterjedésű centrumtérséget (s így a Bumerángot sem) a térszerkezetben.

A zónákhoz kapcsolódóan kísérletet tettünk annak megállapítására, hogy 2000 és 2010 között milyen elmozdulás történt a térség fejlettségi térszerkezetében regionális szinten. A régiók egy főre jutó GDP-értékeinek egymást követő évek közötti korrelációs együtthatói jelzik (rendre 0,995 feletti értékekkel), hogy egyik évről a másikra, de a kezdő és záró év között $(r=0,943)$ sem volt drámai átalakulás. A térszerkezet átalakulásának másik elemzési lehetősége a régiók fejlettségi rangsorban elfoglalt helyzetének időbeli vizsgálata (Gyuris 2012). ${ }^{5}$ A térszerkezetet nem jellemezte állandóság, a régiók kismértékű „mozgásban” voltak, mindössze a fővárosok, a fővárosi térségek és Nyugat-Ausztria fejlettsége, valamint néhány lengyel régió és Kelet-Románia elmaradottsága volt stabil ebben az időszakban (4. ábra). Kelet-Közép-Európa északi felében nem történt komolyabb változás, a déli részben ellenben kiegyenlítődés játszódott le azáltal, hogy Nyugat- és Közép-Romániában makrotérségi pozíciójavulás történt alacsony fejlettségi szintről (ennek eredményeként egy-egy „kisebb foltban” megjelent ezen országban is a fejlettség és gazdasági sürüség), míg Magyarország mintegy kétharmada (12 megye) és Horvátország kontinentális része jelentősen „lecsúszott” a térség fejlettségi térszerkezetében. Mindezek eredményeként a déli térségek egyveretűsége fokozódott (2. ábra). E tény felhívja a figyelmet arra is, hogy bár egy makrorégiót vizsgálunk, ám egyes országok jellemzői (az országok makrogazdasági folyamatai) térben visszatükröződnek, erősítve az egy-egy országhoz tartozás mint magyarázó tényező kötelező figyelembevételét a keletközép-európai regionális vizsgálatokban.

A térség csomópontjainak kategorizálásával az 1. ábrán négyféle típus állt elő: nemzetközi jelentőségű, potenciálisan nemzetközi jelentőségű, transznacionális jelentőségű város, valamint regionális centrum nemzeti jelentőséggel. Új ábránk csomópontjainak kijelölésekor elsőként a kapcsolódó szakirodalom ad információkat. Az ESPON egyik kutatásában (2005) európai városokat rangsoroltak: Bécs ún. MEGA1; Varsó, Prága, Pozsony, Budapest MEGA3; Bukarest, Ljubljana, Katowice, Krakkó, Gdańsk-Gdynia, Wrocław, Poznań, Łódź, Szczecin, 
4. ábra: A gazdasági fejlettség regionális különbségeinek változása Kelet-Közép-Európában a 2000-es években Changing regional inequalities in economic development in East-Central Europe in the 2000s

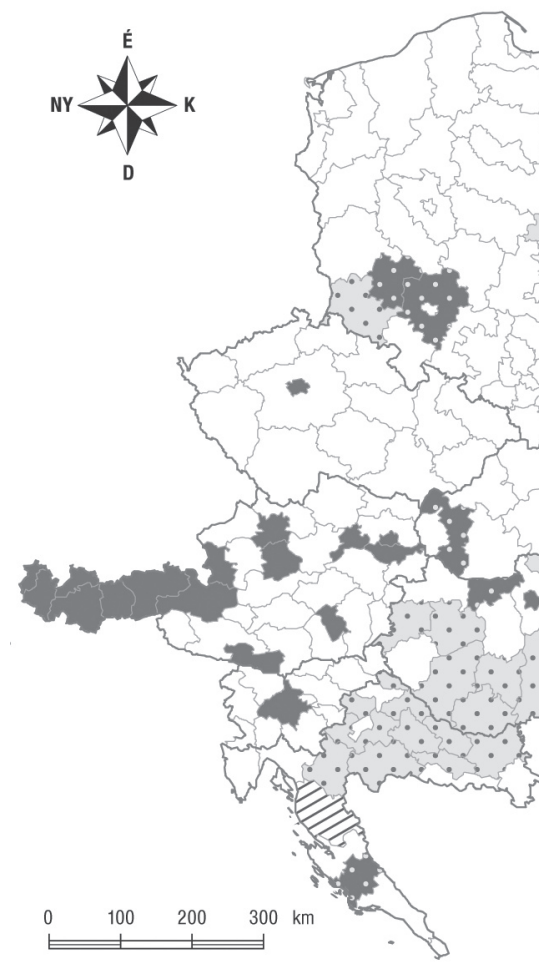

Régiótípusok a fejlettségi rangsorban elfoglalt pozíciók stabilitása és változása alapján

stabilan vezetök

$\because$ feltörekvők

$\because$ leszakadók

$\square$ stabilan utolsók

stagnálók

$\square$ egyéb

Adatok forrása: Eurostat REGIO.

Temesvár a MEGA4 csoportba tartozik. Egy bonni átfogó európai városkutatásban (BBSR 2011) városokat rangsoroltak funkcióik alapján, ebben az alábbi városok jelennek meg térségünkből: Pozsony és Bécs egysége 7. a sorban, később Budapest, Varsó, Prága, majd Bukarest jelenik meg; még hátrébb Zágráb, Krakkó, Ljubljana, majd Brno, Graz, Linz, Innsbruck, Salzburg, Poznań és Wrocław. E két kutatás kijelöli azt a városkört, amelyik az európai városi térben érdemben „megjelenik”.

A hazai munkák a térség nagyvárosait egyrészt általánosan (Jeney 2012; Kovács 2009), másrészt a népességnagyság szerint (Horváth 2007), harmadrészt gazdaságirányító szerepük alapján (Csomós 2011) jellemzik. Előfordul, hogy csak a térség fóvárosait (esetleg egy-két regionális nagyvárost) hasonlítanak össze (pl. Cséfalvay 2010). Ezen túl az egyes országok városállományáról és városairól külön lelhetünk fel információkat (pl. Probáld, Szabó 2007).

Ezekből a munkákból a térszerkezet szempontjából azt tudtuk leszűrni, hogy egyrészt a térségben a nagyvárosi csomópontok gazdasági súlya nő, ezek 
elválaszthatók a városállomány alsó felétől, külön megjeleníthetők. Másrészt Kelet-Közép-Európában minden országban a fővárosok az elsődleges központok, nem találunk makroregionális szinten kiemelkedő gazdasági, politikai funkciójú regionális központot. Harmadrészt a milliós lélekszámú fővárosok után hiányoznak a milliós nagyvárosok, de viszonylag hiányos a 0,5-1 millió fös kategória is (négy lengyel város és Zágráb sorolható ide). A térség történelmi eseményeiből eredően viszont kis népességü, de fővárosi funkciójú városok is bele tartoznak az állományba, amelyek külön kategóriába sorolhatók. Ezeken túl kelet-közép-európai városállományi sajátosság, hogy a szocializmusban akár erőltetetten fejlesztett központok (pl. székhelyek) közül egyesek még jelentős népességkoncentrációval bírnak, ám a piaci folyamatok hatására gazdaságilag meggyengültek (társadalmi csomópontokként működnek). A térség országainak berendezkedése miatt a területi közigazgatási szerepkör Ausztrián kívül nem domináns egy-egy nagyváros életében. A földrajzi fekvés szerepe felértékelődött, az elhelyezkedés megosztó dimenziót jelenthet azonos népességnagyság-kategóriájú városok között, így a nagytérségi, országos szintű városcsoportok például Lengyelországban a főváros mellett komoly gazdasági erővel bírnak (cégközpontok, forgalom stb.). Fontos az is, hogy a nagyvárosok közötti kapcsolatok általában nem erősek, és a globális hálózatba belépve a környezetükhöz (agglomeráció) való viszonyuk is átalakult.

Mivel a térség országainak népességnagysága és az országok városállománya számottevően eltér, így nem egyszerủ a nagyvárosok kategorizálása. ${ }^{6}$ Célszerü a nagyvárosok népességnagyságából kiindulni (amelyet a posztszocialista térségben gyakorlatilag követ a népességet kiszolgáló szektor volumene). A népességszám változója kombinálódik azzal, hogy kisebb lélekszámú fővárosok is vannak, valamint kisebb lélekszámú város is lehet kiemelt regionális nagyváros egy kisebb országban. A lélekszám és az anyaországbeli súly alapján rangsorolt nagyvárosok kategóriáit az 1. táblázat tartalmazza. A táblázatban kirajzolódik az egyes országok városhálózatának jellege: a policentrikus Lengyelország két kategóriába sorolható nagyszámú várossal; Románia hasonlóan két kategóriás köre (a két kör fövároshoz képest kisebb lélekszámával); Magyarország és Ausztria az egykörös, csekély lélekszámú, kelet-közép-európai léptékben középvárosi méretű regionális nagyvárosokkal; Szlovákia és Szlovénia esete egyegy ellenpólussal; Csehország és Horvátország pedig kettő-kettő (esetleg három-három) ellenpólussal (a szlovén és horvát városok közép-európai léptékben szerény súlyúak).

A társadalmi koncentráción és a nemzeti szerepen túl a gazdasági volumen (euróban mért GDP) mutatója lényeges, ezzel a gazdasági koncentrációt mérhetjük. Az Eurostat adatai alapján (amelyekben az egység a nagyvárostérség) az osztrák nagyvárosok emelkednek ki: népességsúlyukhoz képest a gazdasági értéktermelésben elfoglalt helyük jóval jelentősebb a térségben. A többi nagyváros esetében is érzékelhető differencia a népességhez viszonyított súlyban, ami azt sugallja, hogy célszerü a társadalmi és a gazdasági koncentrációt külön is figyelembe venni. 
1. táblázat: A kelet-közép-európai nagyvárosok csoportosítása népességszám és országaik alapján Classification of East-Central European cities based on the population and their countries

\begin{tabular}{|c|c|c|c|c|c|c|c|c|}
\hline $\begin{array}{l}\text { Lakos- } \\
\text { ságszám } \\
\text { (millió } \\
\text { fó) }\end{array}$ & $\begin{array}{l}\text { Lengyel- } \\
\text { ország }\end{array}$ & $\begin{array}{l}\text { Cseh- } \\
\text { ország }\end{array}$ & Románia & $\begin{array}{c}\text { Magyar- } \\
\text { ország }\end{array}$ & Ausztria & $\begin{array}{l}\text { Horvát- } \\
\text { ország }\end{array}$ & Szlovákia & Szlovénia \\
\hline$>1$ & Varsó & Prága & Bukarest & Budapest & Bécs & & & \\
\hline \multicolumn{9}{|l|}{$0,9-1$} \\
\hline \multicolumn{9}{|l|}{$0,8-0,9$} \\
\hline $0,7-0,8$ & $\begin{array}{l}\text { Krakkó, } \\
\text { Łódź }\end{array}$ & & & & & & & \\
\hline $0,6-0,7$ & Wrocław & & & & & Zágráb & & \\
\hline $0,5-0,6$ & Poznań & & & & & & & \\
\hline $0,4-0,5$ & $\begin{array}{l}\text { Gdańsk, } \\
\text { Szczecin }\end{array}$ & & & & & & Pozsony & \\
\hline $0,3-0,4$ & $\begin{array}{l}\text { Bydgoszcz, } \\
\text { Lublin, } \\
\text { Białystok, } \\
\text { Katowice }\end{array}$ & $\begin{array}{l}\text { Brno, } \\
\text { Ostrava }\end{array}$ & & & & & & \\
\hline $0,2-0,3$ & $\begin{array}{l}\text { Gdynia, } \\
\text { Częstochowa, } \\
\text { Radom, } \\
\text { Sosnowiec, } \\
\text { Toruń, Kielce }\end{array}$ & & $\begin{array}{l}\text { Craiova, } \\
\text { Kolozsvár, } \\
\text { Galati, } \\
\text { Constan- } \\
\text { ța, Jászvá- } \\
\text { sár, Te- } \\
\text { mesvár, } \\
\text { Brassó, } \\
\text { Ploiești, } \\
\text { Brăila, } \\
\text { Nagyvárad }\end{array}$ & Debrecen & Graz & & Kassa & Ljubljana \\
\hline $0,1-0,2$ & $\begin{array}{l}\text { Gliwice, } \\
\text { Zabrze, } \\
\text { Olsztyn, } \\
\text { Bytom, } \\
\text { Rzeszów, } \\
\text { Bielsko-Biała }\end{array}$ & Plzeň & $\begin{array}{l}\text { Bákó, } \\
\text { Pitești, } \\
\text { Arad, } \\
\text { Nagy- } \\
\text { szeben, } \\
\text { Nagybá- } \\
\text { nya, Buzău, } \\
\text { Maros- } \\
\text { vásárhely }\end{array}$ & $\begin{array}{l}\text { Miskolc, } \\
\text { Szeged, } \\
\text { Pécs, Győr }\end{array}$ & $\begin{array}{l}\text { Linz, } \\
\text { Salzburg, } \\
\text { Innsbruck }\end{array}$ & $\begin{array}{l}\text { Split, } \\
\text { Rijeka }\end{array}$ & & \\
\hline
\end{tabular}

Megjegyzés: a fóvárosokat aláhúzással, a saját országukban nagyvárosi szerepkört betöltóket álló, a középvárosi szerepkört betöltőket dölt betüvel jelöltük.

Adatok forrása: Eurostat REGIO, The World Gazetteer. 
Utolsó szempontként azt emeljük ki, hogy az átfogó kép megalkotása miatt nem az országon, hanem a vizsgált térségen belüli súlyokat tekintettük át, nem részleteztük a városhálózatot, emiatt az eredeti ábrához képest a „regionális központok nemzeti jelentőséggel" kategóriáját kisebb súllyal vettük figyelembe.

Eredményként az alábbi rangsort kaptuk a kelet-közép-európai térszerkezetre. Bécs városát külön kategóriába emeltük ki (társadalmi és gazdasági csomópont, fővárosi funkcióval, nemzetközi és európai jelentőséggel). Ezt követi Varsó, Prága, Budapest és Bukarest (társadalmi és gazdasági csomópont, fóvárosi funkcióval, európai jelentőséggel). A következő kategória Pozsony, Zágráb, Ljubljana (társadalmi és gazdasági csomópont, fővárosi funkcióval). Ezután következnek a regionális nagyvárosok (kisebb csomópontok), amelyek három alkategóriába sorolhatók, a gazdasági (GDP) és a társadalmi (népesség) súly viszonyától függőn. Ahol a kettő aránya átlagos, azok „társadalmi és gazdasági csomópontok" (Łódź, Wrocław, Poznań, Krakkó, Brno, Ostrava és Kassa). A nagy gazdasági súly révén külön alkategóriát jelentenek az osztrák nagyvárosok (Graz, Linz, Salzburg, Innsbruck), különállásukat erősíti, hogy a térségben ezeknek a nagyvárosoknak van érdemi területi közigazgatási szerepköre (tartományi központok). A harmadik alkategóriába kerültek azok a nagyvárosok, ahol a népességsúly nagyobb, mint a gazdasági (Szczecin, Bydgoszcz, Lublin, Białystok, Craiova, Kolozsvár, Galați, Constanța, Jászvásár, Temesvár, Brassó). Külön kategóriát alakítottunk ki a „kelet-közép-európai megalopoliszoknak”, amelyekből kettő található a térségben: a Katowice-központú városhalmaz (Bytom, Gliwice stb.) és a Gdańsk-Gdynia-Sopot városhármas. Itt meghúztuk a határt, mivel az ezt követő városok társadalmi-gazdasági súlya már egy szint alá ér, és innentől már egy újabb, elég bő regionális nagyvárosi kör kezdődik.

Térszerkezeti szempontból a csomópontok holdudvara is az ábrára kívánkozik, amelyek megállapításához a gazdasági sűrűség térképét hívtuk segítségül: ahol a nagyváros vagy annak régiója magasabb gazdasági sűrűségű volt, ott külön feltüntettük a nagyvárosi erőteret.

A kelet-közép-európai tengelyek esetében az 1. ábrán nyugatról kelet felé húzódó „európai közlekedési folyósok” találhatók. Feltételezheto, hogy nem a térségbeli csomópontok között vannak a fó áramlások, hanem e csomópontok, valamint főként a centrumtérség (benne Németország mint vezető külkereskedelmi partner) vagy a világ más kiemelkedő gazdasági térségei között (akár a centrumon keresztül); az áramlás volumene azonban közepes (holdudvarszerep). A tranzitjelleg miatt e térségen keresztül nyersanyag, áru, munkaerő áramlik a centrum és a kontinens déli és keleti perifériája között, amelynek volumene európai viszonylatban szintén közepes.

A közlekedési tengelyek esetében fontos a közúti és a vasúti forgalom nagysága (ezek alappályáinak elhelyezkedése hasonló a térség adottságai miatt), mivel ezek jelölik ki a fö tengelyeket Kelet-Közép-Európa térszerkezetében; a minőség (autópálya léte vagy hiánya, gyorsvasút) viszont a forgalom szempontjából másodlagos. A hajózásban érdemi folyosó (térszerkezeti elem) mind- 
össze a Duna. (A légi forgalom nem vetül rá a földrajzi térre, és inkább a térségen kívülre irányuló volumene a meghatározó.) Összességében úgy látjuk, hogy a térszerkezeti tengelyek felrajzolásához az alapot a páneurópai hálózat jelentheti. ${ }^{7}$ Ezek összesített forgalmára azonban nincsenek adatok, azaz a tengelyeket nem kategorizáljuk térszerkezeti ábránkon. (A 2000. évre vonatkozó európai közúti forgalomnagyság-térkép szerint a vizsgált térségben csak a fóvárosok körül, illetve Ausztria fö áramlási zónájában volt nyugati szintű forgalom.)

Végezetül fontos kiemelni Kelet-Közép-Európa térszerkezetének egyedi földrajzi tereit. Régebben a nagy bányászati-ipari körzetek voltak ilyenek, ezekből több szerepel az eredeti ábrán. Ezek mára többségükben meggyengültek, s választott elemtípusainknál, léptékünkben külön nem bukkannak fel (esetleg nagyvárosi csomópontként megmaradt a központjuk, társadalmi súlyuk nagyobb, s emiatt az elmaradott térségek kategóriájába kerültek). A modern ipar a csomópontokba koncentrálódik.

A szolgáltató szektorra a pontszerüség jellemző. Jelentősebb területfoglaló az idegenforgalmi körzet (Rechnitzer 2013), és ez a térszerkezeti ábránkra is

5. ábra: Kelet-Közép-Európa térszerkezeti képe a 2010-es évek elején

The spatial structure of East-Central Europe, early 2010s

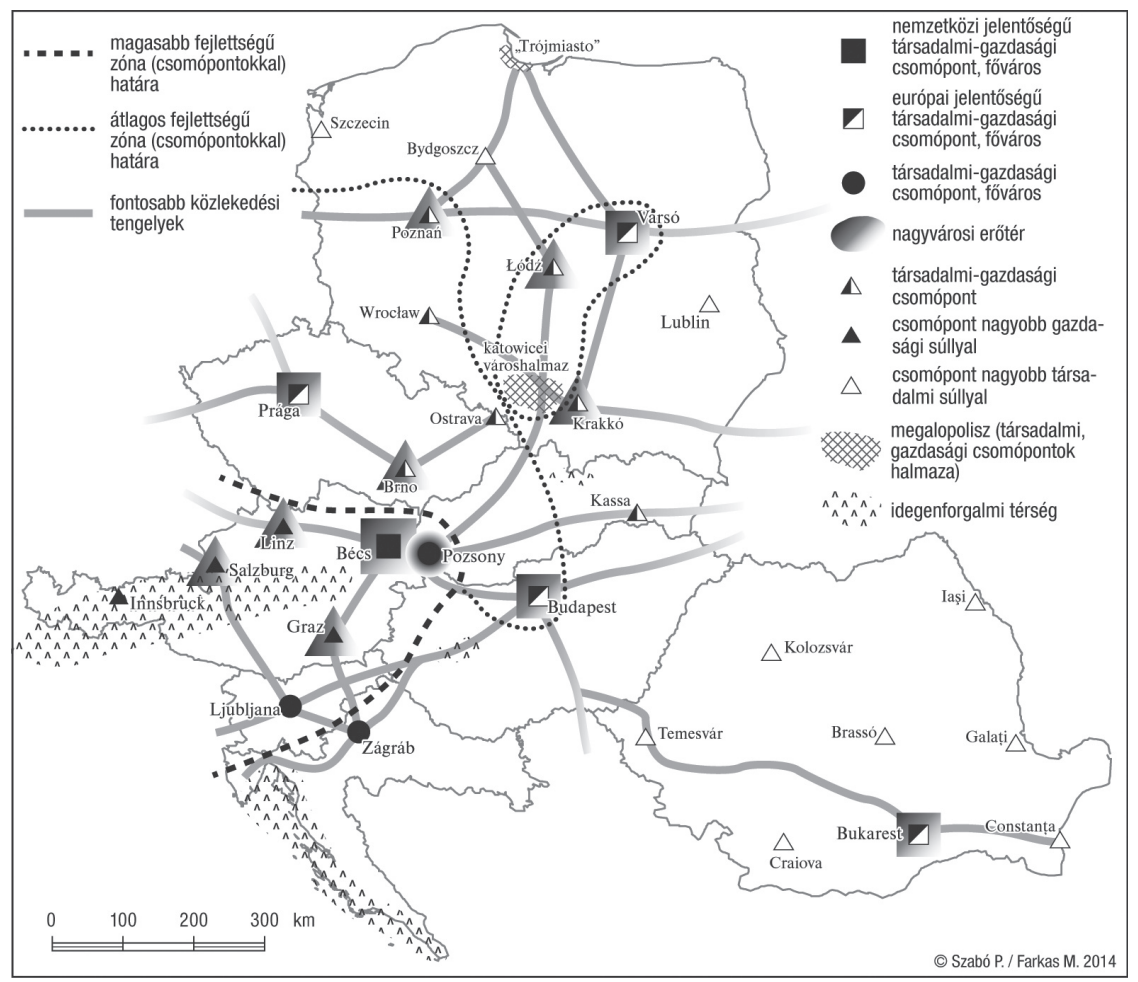


felkívánkozik: a horvátországi tengerpart, az Alpok, a Balaton és a szlovák-lengyel Magas-Tátra; ebben tehát nincs változás az előző térszerkezeti ábrához képest.

Kelet-Közép-Európa térszerkezeti elemeit az 5. ábrán összegeztük. A „bumerángkérdésre" válaszolva nem találjuk célravezetőnek összefüggő koncentráció bejelölését, mivel a nyugati centrumtérségjelleg (nagyvárosi konglomerátumok és ezek összefüződése, szoros kapcsolatrendszere sűrü tengelyekkel) nem jellemző Kelet-Közép-Európára. Felső-Szilézia nem erős és nem dinamikus térség, a Bécs-Pozsony(-Győr) agglomeráció pedig nem igazán terjeszkedik a földrajzi térben. A többi csomópont magányos, és inkább „nyugat felé tekint”.

Végezetül azt emelnénk ki, hogy ebben a közelítésben kidomborodik a regionális különbségek szerepe: bár sok a közös társadalmi, gazdasági vonás (kifejezetten a posztszocalista országok esetében), ám az egyes országok térszerkezeti szempontból különböznek egymástól. Megfigyelhető, hogy miközben egyes országok részben különböző térszerkezeti problémákkal küzdenek, ugyanakkor térszerkezeti szempontból mégis viszonylag egységes az egyes országok regionális politikája, például általánosan jellemző a fejlesztési pólusok és tengelyek kijelölése (részletesebben lásd Fábián, Forman 2011; Szabó 2012a, 2012b).

\section{Zárszó}

Zárásként a makrorégiók regionális politikai szerepére hívnánk fel a figyelmet. Egyrészt arra a dokumentumra, amely az ilyen jellegű tudományos vizsgálatok szakpolitikai igényét mutatja (V4+2 2010). Az anyag hat ország (visegrádi négyek, Románia és Bulgária) területfejlesztési hivatalainak közös munkája, megpróbálja a hat ország területfejlesztési elképzeléseit összesíteni, s ezeket ábrákon is bemutatni. A dokumentum igazolja, hogy miért fontos a regionális politika esetében a térszerkezetről ilyen földrajzi terekben, léptékekben is gondolkodni. Például ha „összetoljuk” az egyes országok térszerkezet-fejlesztési elképzeléseit, kiderül, hogy milyen térszerkezet-fejlesztési konfliktusok vannak (össze nem érő fejlesztési tengelyek, szomszédos országbeli, közeli csomópontok hasonló irányú fejlesztése stb.). Másrészt kiemelhető, hogy új irányzatként hódít az európai kohéziós politikában a földrajzi alapú makrorégiókban való gondolkodás. Hazánkat a Duna régió (és stratégia) érinti, amely gyakorlatilag egy markáns földrajzi elemre épített térszerkezeti formáció. Ugyanakkor ebből a szempontból eléggé vitatható is, mivel e térségnek nem térszerkezeti alapja a Duna, egyelőre sokkal inkább a közös múltból eredő társadalmi és gazdasági jellemzők a domináns összekötő elemek a térségben, nem pedig a földrajziak (a kelet-közép-európai fekvésen, illetve az európai centrum és periféria közé zártságon túl). 


\section{Jegyzetek}

1 A részletesebb kutatási anyag 2014-ben jelenik meg, ebben több olyan elemet részletesebben kifejtünk, amelyeket itt a cikk terjedelmi korlátai miatt nem vagy csak részben tárgyalunk.

2 Kelet-Közép-Európa lehatárolása vitatott Európában. Rengeteg munka foglalkozik a kérdéssel, ráadásul a vizsgálatok például a cél vagy a rendelkezésre álló adatok miatt el-eltérnek egymástól a területi keretben. Kutatásunkban több szempontot igyekeztünk figyelembe venni: országokat vettünk alapul, egységes adatbázist akartunk feldolgozni, és legfontosabbként Kelet-Közép-Európát magyar szemszögből néztük. Így hazánkon kívül Lengyelországot, Csehországot, Szlovákiát, a jugoszláv utódállamok közül Szlovéniát és Horvátországot soroltuk ide, valamint a több helyütt kérdéses Romániát is bevettük a vizsgálatba. Ezen túl a szomszédos Ausztria is bekerült, egyrészt az Osztrák-Magyar Monarchia történeti öröksége, másrészt a magyar szomszédság miatt. Mivel Németországot ketté kellett volna osztani, és az egykori NDK lett volna csak a vizsgálat tárgya, így azt végül kihagytuk. (Az európai uniós „feloldott” határok ellenére egy-egy ország térszerkezete erős és koherens, és - mint ahogy az egy főre jutó GDP térképei mutatják vagy ahogy Egri, Litauszky (2012) és Lengyel (2012) munkája is bemutatta - a volt NDK napjainkban már egy külön társadalmi-gazdasági klasztert alkot a vizsgált térségben.) Bár magyar szemszögből Ukrajna (legalábbis annak egy része) és Szerbia még szóba jöhetett volna, de mind makroregionális besorolásuk, mind EU-n kívüliségük (adathiány, schengeni határok stb.) miatt kihagytuk őket. Így végezetül egy „közép-kelet európai uniós" térséget (az EU keleti felének középső részét) határoltunk le.

3 A gazdasági sűrűség mutatója felbontható a GDP/népesség és a népesség/terület szorzatára, azaz ha magas az értéke, akkor az nemcsak gazdasági, de társadalmi koncentrációt is jelez.

4 A fejlettség (életminőség) vizsgálatánál a vásárlóerő-paritáson mért egy főre jutó GDP a célszerủ mutató, ugyanakkor a térségbeli területi koncentráció kimutatásánál (gazdasági sűrüség) az euróban mért.

5 A fejlettségi rangsorban a vizsgált tíz év alatt elfoglalt legjobb és legrosszabb helyezések közötti különbség (,abszolút mozgás”), valamint a helyezések mediánértéke alapján a régiókat csoportosítani lehet. Stabil helyzetben lévő térségeknek azokat a régiókat tekintettük, ahol az abszolút mozgás nem haladta meg a 15 helyezést, ezen belül pedig stabilan utolsó, illetve stabilan éllovas régiókat különítettünk el (előbbiek helyezéseinek mediánja 150 feletti, utóbbiaké 20 alatti volt). Azon területegységek között, amelyek rangsorban elfoglalt pozíciói között több mint 40 helyezésnyi különbség volt (42 db) elkülönítettük azokat, amelyek pozícióromláson és pozíciójavuláson mentek keresztül.

6 Az egyenlőtlenséget mutatja, hogy a 89 db 100 ezer főnél népesebb város között Szlovákia két várossal, Szlovénia egy várossal képviselteti csak magát, ugyanakkor 39 lengyel és 24 román város van a csoportban.

7 Az európai hálózatban a kilencvenes években közlekedési folyosókat jelöltek ki: a tíz folyosó a transzeurópai közlekedési hálózat (TEN-T) kiterjesztése volt az akkori Európai Unió szomszédos államai irányába; az EU bővítése révén ezek a folyosók ma már nagyrészt az EU területén haladnak, így a transzeurópai közlekedési hálózat (TEN-T) részét képezik.

\section{Irodalom}

Artelaris, P., Kallioras, D., Petrakos, G. (2010): Regional inequalities and convergence clubs in the European Union new member-states. Eastern Journal of European Studies, 1., 113-133.

BBSR (2011): Metropolitan areas in Europe. Federal Institute for Research on Building, Urban Affairs and Spatial Development, Berlin. http://www.espon-sespon.eu/dane/web_usespon_libraryfiles/1200/de_metroareaeu_2011.pdf (Letöltés: 2013. augusztus 27.) 
Cséfalvay Z. (1999): Helyünk a nap alatt... Magyarország és Budapest a globalizáció korában. Kairosz Kiadó, Budapest

Cséfalvay Z. (2010): Poszt-metropolisz után - globális recesszió és városfejlődés Kelet- és Közép-Európában. Corvinus Regionális Tanulmányok, 2-3., 5-20.

Csomós Gy. (2011): A közép-európai régió nagyvárosainak gazdaságirányító szerepe. Tér és Társadalom, 3., 129-140.

Dijkstra, L., Annoni, P., Kozovska, K. (2011): A new regional competitiveness index: theory, methods and findings. Directorate-General for Regional Policy Working Papers, 2. http://ec.europa.eu/regional_policy/sources/docgener/work/2011_02_competitiveness.pdf (Letöltés: 2013. augusztus 25.)

Egri Z., Törőcsik V., Tánczos T. (2009): Regional HDI as a territorial and social differentiation index in Central Europe. In: Káposzta J. (ed.): New elements and research in spatial economy. Selye University Research Institute, Komárno, 165-180.

Egri Z., Litauszky B. (2012): Térszerkezeti sajátosságok Közép-Kelet-Európában. http://www.mrtt.hu/ vandorgyulesek/2012/2/egri.ppt (Letöltés: 2013. november 20.)

ESPON 111. (2005): Potentials for polycentric development in Europe. http://www.espon.eu/export/sites/ default/Documents/Projects/ESPON2006Projects/ThematicProjects/Polycentricity/fr1.1.1_re vised-full.pdf (Letöltés: 2013. augusztus 29.)

Fábián A., Forman B. (2011): Alkalmazott strukturális politikák Közép-Európában (2000-2013). Nyugatmagyarországi Egyetem Kiadó, Sopron

Fábián Zs. (2011): The role of neighbourhood in the regional distribution of Europe. Területi Statisztika, 14., 122-134.

Farkas M. (2010): Területi fejlettségi különbségek, konvergencia és térszerkezet Spanyolországban. Területi Statisztika, 6., 674-687.

GAWC (2012): The world according to GaWC 2012. http://www.lboro.ac.uk/gawc/world2012t.html (Letöltés: 2013. november 20.)

Gorzelak, G. (1996): The regional dimension of transformation in Central Europe. Regional Studies Association, London

Gyuris F. (2012): A területi szerkezet stabilitásának néhány elemzési lehetősége a területi kutatásokban a kínai gazdaság példáján. In: Nemes Nagy J. (szerk.): Térfolyamatok, térkategóriák, térelemzés. ELTE Regionális Tudományi Tanszék, Budapest, 80-98. (Regionális Tudományi Tanulmányok; 16.)

Haggett, P. (2006): Geográfia. Globális szintézis. Typotex, Budapest

Heyns, B. (2005): Emerging inequalities in Central and Eastern Europe. Annual Review of Sociology, 31., 163-197.

Horváth Gy. (2007): Régióközpontok Európában. Magyar Tudomány, 6., 704-720.

Horváth Gy. (2009): Regionális egyenlőtlenségek a kelet- és közép-európai kutatási térségben. Magyar Tudomány, 12., 1499-1512.

Jeney L. (2012): Városföldrajz. In: Jeney L., Kulcsár D., Tózsa I. (szerk.): Gazdaságföldrajzi tanulmányok közgazdászoknak. BCE Gazdaságföldrajzi és Jövőkutatási Tanszék, Budapest, 39-70.

Kincses Á., Nagy Z., Tóth G. (2013): Európa térszerkezete különböző matematikai modellek tükrében, I. rész. Területi Statisztika, 2., 148-156.

Kovács Z. (2009): Az urbanizáció keresztútja Kelet-Közép-Európában. Változó Föld, változó társadalom, változó ismeretszerzés. 460., 44-51.

Kunzmann, K. R. (1992): Zur Entwicklung der Stadtsysteme in Europa. Mitteilungen der Österreichischen Geographischen Gesellschaft, 134., 25-50.

Kunzmann, K. R. (2001): La "Banane bleue" est morte! Vive la "Grappe européenne"! Conseil général des Ponts et Chaussées, Ministère de l'Equipement des Transports et du Logement, Paris, 38-41. (Les Cahiers du Conseil; 2.)

Kuttor D. (2009): Different regions - Regional differences in the Visegrad Four countries. In: Káposzta J. (ed.): New elements and research in spatial economy. Selye University Research Institute, Komárno, 60-72.

Lengyel I. (2012): A kelet-közép-európai országok régióinak versenyképessége. In: Rechnitzer J., Smahó M. (szerk.): Jármüipar és regionális versenyképesség. Széchenyi István Egyetem, Győr, 191-229. 
Nemes Nagy J. (1987): A regionális gazdasági fejlódés összehasonlitó vizsgálata. Akadémiai Kiadó, Budapest Pénzes J. (2013): The dimensions of peripheral areas and their restructuring in Central Europe. Hungarian Geographical Bulletin, 4., 373-386.

Probáld F., Szabó P. (szerk.) (2007): Európa regionális földrajza II. Társadalomföldrajz. ELTE Eötvös Kiadó, Budapest

Rechnitzer J. (1998): Területi stratégiák. Dialóg Campus Kiadó, Budapest, Pécs

Rechnitzer J., Smahó M. (2011): Területi politika. Akadémiai Kiadó, Budapest

Rechnitzer J. (2013): Adalékok Kelet-Közép-Európa térszerkezetének felrajzolására. Geopolitika a XXI. században, 4., 35-52.

SIC! (2006): Sustrain implement corridor. Short factbook. http://www.landesentwicklung.sachsen.de/download/Landesentwicklung/SIC_ShortFactbook_en_060907.pdf (Letöltés: 2014.január 8.)

Szabó P. (2008): A térszerkezet fogalma, értelmezése. Tér és Társadalom, 4., 63-80.

Szabó P. (2009): Európa térszerkezete különböző szemléletek tükrében. Földrajzi Közlemények, 2., 121-134

Szabó P. (2010): A térszerkezet kartografikus megjelenítése a hazai regionális szintű területfejlesztési dokumentumokban. Falu-Város-Régió, 2-3., 28-34.

Szabó P. (2011): A térszerkezet jellemzői a megyei területfejlesztési dokumentumokban. Comitatus, 11., 3-16.

Szabó P. (2012a): Térszerkezeti modell - területszerkezeti ábra. In: Nemes Nagy J. (szerk.): Térfolyamatok, térkategóriák, térelemzés. ELTE Regionális Tudományi Tanszék, Budapest, 187-197. (Regionális Tudományi Tanulmányok; 16.)

Szabó P. (2012b): Térszerkezeti ábrák a Visegrádi országok területfejlesztési gyakorlatában. In: Berghauer S., Dnyisztrjanszkij, M., Fodor Gy., Gönczy S., Izsák T., Molnár J., Molnár D.I. (szerk.): Társadalomföldrajzi kihívások a XXI. század Kelet-Közép-Európájában. II. Rákóczi Ferenc Kárpátaljai Magyar Főiskola, Beregszász, 167-175.

Tagai G. (2004): Kelet-Közép-Európa gazdasági és népességi potenciáltere. MTA Közgazdaságtudományi Intézet Mühelytanulmányok, 26.

V4+2 (2010): Common spatial development document of the V4+2 countries. www.mmr.cz/getmedia/e29f36f6df9d-468a-89e9-01673f5192ea/V4plus2_Document_eng_ok.pdf (Letöltés: 2014. január 7.) 